
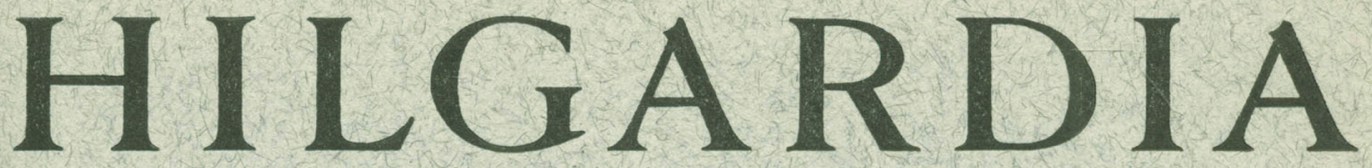

A Journal of Agricultural Science Publisbed by the California Agricultural Experiment Station

\title{
DALAPON, AMITROLE, AND WEED OIL COMPARED FOR EFFECTIVENESS IN CONTROL OF BERMUDAGRASS IN CALIFORNIA CITRUS ORCHARDS
}

B. E. DAY, C. D. MCCARTY, and L. S. JORDAN 
Dalapon, amitrole, and weed oil, used alone, as mixtures, or in combination, were compared for effectiveness in the control of bermudagrass. Split applications of dalapon, properly timed, were more effective than single applications with the same total amount of herbicide. Amitrole, and to a lesser extent dalapon, was more effective when applied late in the growing season. Variation in spray volume, the presence or absence of surfactant, or the inclusion of small amounts of kerosene had no effect on the toxicity of amitrole. Mixtures of dalapon and amitrole were less toxic than was dalapon applied alone at the same rate. Split applications of amitrole were less effective than single applications containing the same total amount of herbicide.

Repeat spraying with weed oil at three-week intervals was highly effective and gave control equal to the more frequent oil spraying.

In a screening program, atratone and prometone at rates of 10 pounds per acre controlled bermudagrass. Ipazine, trietazine, simetone, simazine, CIPC, EPTC, and maleic hydrazide were not highly toxic to bermudagrass. Sodium 2,3-dichloroisobutyrate was only an eighth as effective as dalapon.

This paper reports research on the evaluation of several chemicals as herbicides for the control of bermudagrass. No recommen. dations for or against the use of these chemicals are intended or implied. Federal and state laws regulate the use of agricultural chemicals, and persons wishing to use chemicals mentioned in this publication should consult local agricultural regulatory officials. 


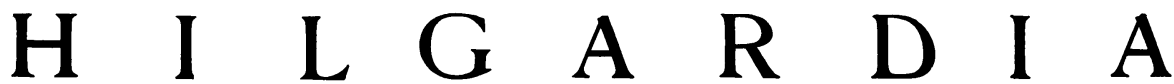

A Journal of Agricultural Science Published by

the California Agricultural Experiment Station

VOL. 32

FEBRUARY, 1962

No. 2

\section{DALAPON, AMITROLE, AND WEED OIL COMPARED FOR EFFECTIVENESS IN CONTROL OF BERMUDAGRASS IN CALIFORNIA CITRUS ORCHARDS ${ }^{1,2}$}

\section{B. E. DAY, ${ }^{3}$ C. D. MCCARTY, ${ }^{4}$ and L. S. JORDAN ${ }^{5}$}

\section{INTRODUCTION}

Bermudagrass (Cynodon dactylon (L.) Pers.) is a serious perennial weed in California citrus orchards. Monuron (3-(p-chlorophenyl)-1,1-dimethyl urea), widely used for control of annual weeds in citrus, is not effective against established bermudagrass at the rates that may be safely employed in orchards (Day, 1955; Day and McCarty, 1957). ${ }^{6}$ On the contrary, use of monuron encourages the vegetative spread of bermudagrass in orchards by eliminating other weed competition. Frequent cultivation suppresses bermudagrass, but is not suited to the nontillage soil management programs commonly employed in citrus culture (Day, 1957). The systemic herbicides, 2,2-dichloropropionic acid (dalapon) and 2-amino 3,4-triaziole (amitrole), although effective for control of the grass, often enter the soil in sufficient amounts to injure citrus trees (Day, 1957; Kretchman, 1961). Citrus is relatively sensitive to soil contamination by both amitrole and dalapon (Day, 1958; Burt and McCown, 1959). Repeated spraying with weed oil, effective and noninjurious to orchard trees, is too expensive for general use.

The limiting factor in the use of dalapon and amitrole is the hazard of tree injury and in the use of weed oil the expense of multiple treatments. Both limitations could be overeome if the herbicidal efficiency of the materials could be increased. More efficient use of dalapon and amitrole might permit reduction of dosages to levels tolerated by the trees. More effective use of weed oil could reduce costs to economic levels feasible for general use in citrus culture.

\footnotetext{
${ }^{1}$ Submitted for publication July 5, 1961.

${ }^{2}$ Paper No. 1329, University of California Citrus Research Center and Agricultural Experiment Station, Riverside.

${ }^{3}$ Associate Plant Physiologist, Citrus Research Center and Agricultural Experiment Station, Riverside.

${ }^{4}$ Associate Agriculturist, Agricultural Extension, Riverside.

${ }^{5}$ Assistant Plant Physiologist, Citrus Research Center and Agricultural Experiment Station, Riverside.

"See "Literature Cited" for citations referred to in the text by author and date.
} 
This paper reports results of a general study of the response of bermudagrass to herbicides under orchard conditions. The objectives were: (1) to screen several herbicides for bermudagrass control; and (2) to determine the most efficient and safe use of dalapon, amitrole, weed oil, and combinations of these herbicides for bermudagrass control in citrus orchards.

\section{MATERIALS AND METHODS}

Experiments were conducted at selected locations in citrus orchards having dense and uniform stands of bermudagrass. The grass was mowed regularly to maintain a height of 2 to 4 inches except when height of the grass was controlled as a factor in the experiments. The areas were watered as needed, by overhead sprinklers. Plots 5 feet wide and 15 feet long were laid out at right angles to the tree rows and treated by means of a hand-propelled, precision sprayer mounted on bicycle wheels. Treatment and control plots were randomized in eight replicated blocks. All applications were made at a uniform volume of 100 gallons per acre except in those tests in which spray volume was the variable studied. A commercial wetting agent ${ }^{7}$ was added to all aqueous sprays except when the effect of absence of surfactant was tested.

The weed oil used in the experiments was a commercial grade containing 70 per cent aromatic constituents without fortifying or emulsifying agents. A commercial formulation of the sodium salt of dalapon containing surfactant and a 50 per cent formulation of amitrole without surfactant were used. The other herbicides used were commercial or experimental formulations supplied by several manufacturers. All applications were made on an acid-equivalent or active-ingredient basis.

Plots were evaluated by visual ratings of injury. Independent observations were made weekly by three or more observers. The ratings were averaged to obtain an estimate of control. Results were analyzed by analysis of variance, multiple range test.

\section{RESULTS Screening Trials}

The results of the screening trials are presented in table 1 . The maximum visible injury (control) obtained at any time during the trials is shown for the following herbicides: atratone (2-methoxy-4-ethylamino-6-isopropylamino-s-triazine); prometone (2-methoxy-4,6-bis (ethylamino)-s-triazine); propazine (2-chloro-4-6-bis (isopropylamino) -s-triazine) ; trietazine (2-chloro4-diethylamino-6-ethylamino-s-triazine) ; ipazine (2-chloro-4-diethylamino-6isopropylamino-s-triazine) ; simetone (2-methoxy-4-6-bis (ethylamino)-s-triazine) ; simazine (2-chloro-4-6-bis (ethylamino)-s-triazine) ; FW-450 (sodium$\alpha, \beta$-dichloroisobutyrate); diquat (1, 1'-ethylene-2,2'-dipyridylium dibromide) ; CIPC (isopropyl N-(3-chlorophenyl) carbamate); EPTC (ethyl N, $\mathrm{N}$-di-n-propylthiocarbamate); and $\mathrm{MH}$ (1,2-dihydropyridazine-3,6-dione). The injury was relatively temporary in some instances.

Where effective, the control given by the triazines was relatively lasting. Peak injury occurred about a month after treatment, and some control remained after five months. The symptoms caused by FW-450 were similar to those caused by dalapon; however, the rates required to produce comparable

\footnotetext{
${ }^{7}$ Formula X-77, supplied by Colloidal Products Company.
} 
injury to the grass were about eight times greater than those for dalapon. Diquat caused rapid dessication of the leaves with little apparent injury to stem tissue. Recovery was rapid. MH caused a blue to blue-gray discoloration of the grass and protracted growth inhibition.

TABLE 1

CONTROL OF BERMUDAGRASS BY VARIOUS HERBICIDES

\begin{tabular}{|c|c|c|}
\hline Herbicide & $\begin{array}{c}\text { Applica- } \\
\text { tion } \\
\text { rate }^{*}\end{array}$ & Control $\uparrow$ \\
\hline 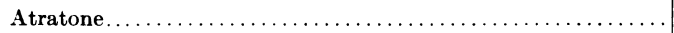 & 5 & 5.7 \\
\hline 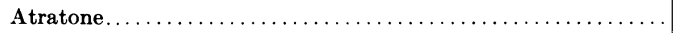 & 10 & 7.4 \\
\hline Atratone $\ldots \ldots \ldots \ldots \ldots \ldots \ldots \ldots \ldots \ldots \ldots \ldots \ldots \ldots \ldots$ & 15 & 8.6 \\
\hline 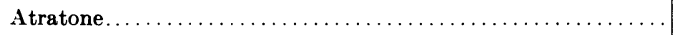 & 20 & 8.7 \\
\hline Prometone $\ldots \ldots \ldots \ldots \ldots \ldots \ldots \ldots \ldots \ldots \ldots \ldots \ldots \ldots$ & 5 & 3.9 \\
\hline Prometone & 10 & 7.8 \\
\hline Prometone & 15 & 8.1 \\
\hline 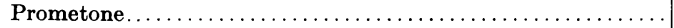 & 20 & 8.7 \\
\hline Propazine.$\ldots \ldots \ldots \ldots \ldots \ldots \ldots \ldots \ldots \ldots \ldots \ldots \ldots \ldots \ldots \ldots \ldots \ldots \ldots$ & 6 & 1.2 \\
\hline Trietazine $\ldots \ldots \ldots \ldots \ldots \ldots \ldots \ldots \ldots \ldots \ldots \ldots \ldots \ldots \ldots$ & 6 & 2.2 \\
\hline Ipazine $\ldots \ldots \ldots \ldots \ldots \ldots \ldots \ldots \ldots \ldots \ldots \ldots \ldots \ldots \ldots \ldots$ & 6 & 2.2 \\
\hline 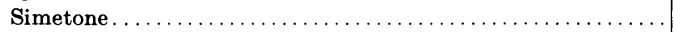 & 6 & 0.0 \\
\hline Simazine ............. & 6 & 2.1 \\
\hline 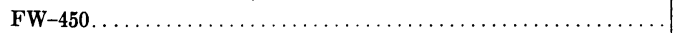 & 6 & 1.0 \\
\hline $\mathrm{FW}-450 \ldots \ldots \ldots \ldots \ldots$ & 12 & 1.2 \\
\hline 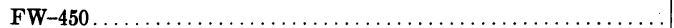 & 24 & 5.0 \\
\hline 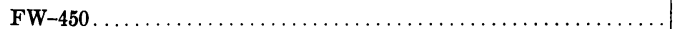 & 48 & 7.3 \\
\hline 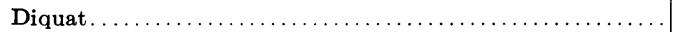 & 1 & 10.0 \\
\hline CIPC & 6 & 1.0 \\
\hline 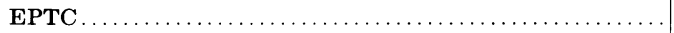 & 6 & 1.5 \\
\hline $\mathbf{M H}$ & 6 & 0.5 \\
\hline 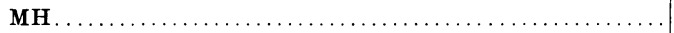 & 12 & 3.2 \\
\hline 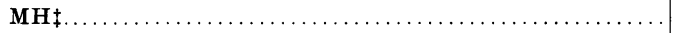 & 6 & 0.5 \\
\hline $\mathbf{M}$ & 12 & 3.5 \\
\hline
\end{tabular}

* Pounds of active ingredient, or acid equivalent per acre.

$\dagger 0=$ no control; $10=$ complete control.

$\ddagger$ Formulated with humectant for conditions of low humidity.

The typical response of bermudagrass to single applications of weed oil, amitrole, and dalapon is shown in figure 1 . Weed oil was applied at the rate of 100 gallons per acre. Amitrole was applied at rates of 6 and 12 pounds per acre, and dalapon at $3,6,9$, and 12 pounds per acre. The plots were treated on August 30, and rated over an 11-week period terminating on November 14, by which date the grass had become dormant due to cold weather.

Dalapon and amitrole gave excellent control in all cases with the exception of dalapon at the 3-pound rate. Maximum injury to the grass following dalapon and amitrole treatments was observed on the fourth week, after which recovery began. The rate of recovery from all three herbicides was relatively slow in these late-season applications, as may be noted from the comparative seasonal effects shown in figures 2,3 , and 4.

Regrowth following weed-oil treatment was rapid during the summer months (fig. 2), but became slower during the fall. A single treatment with weed oil was observed to have a "renovating" effect on bermudagrass. Regrowth was vigorous and rapid and, once recovered, the grass was greener and more luxuriant than were untreated stands. 


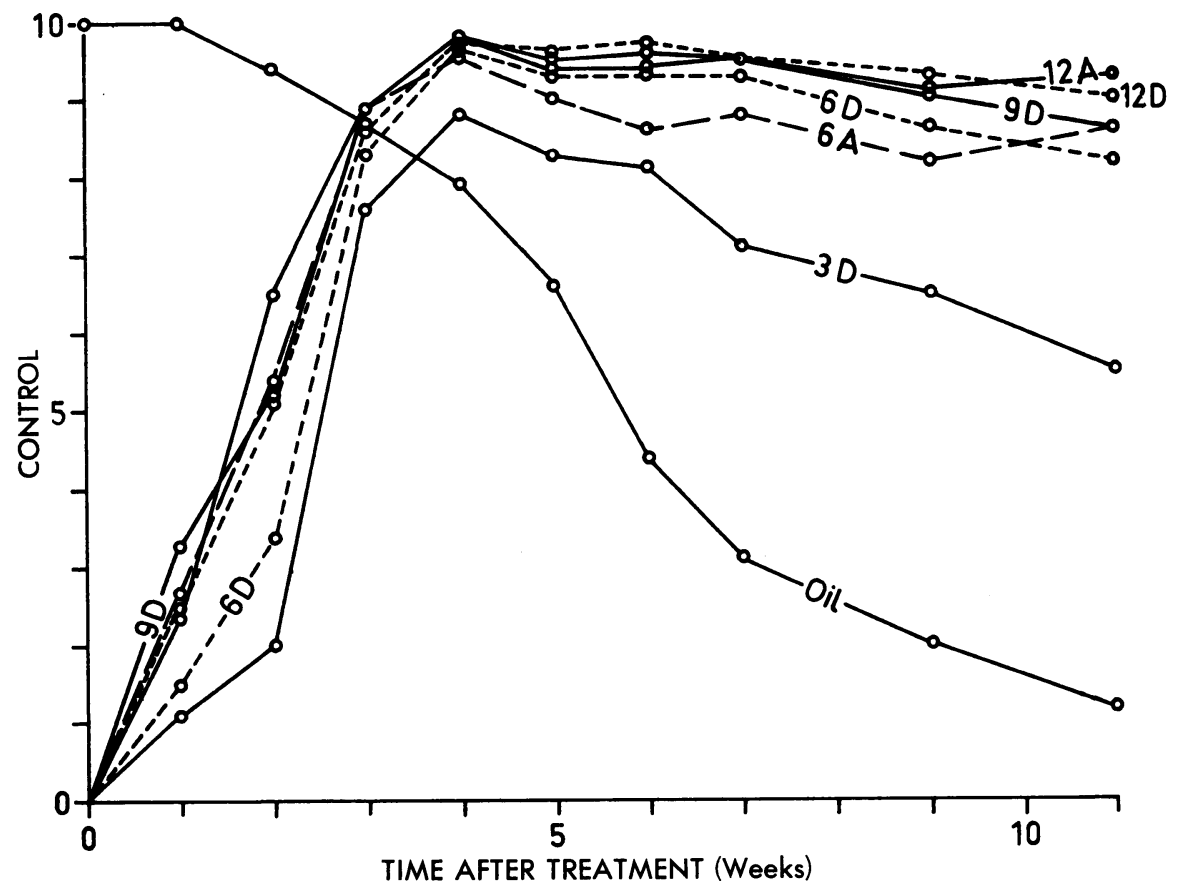

Fig. 1. Response of bermudagrass to weed oil at 100 gallons per acre; to dalapon (D) at $3,6,9$, and 12 pounds per acre; and to amitrole (A) at 6 and 12 pounds per acre. The responses to weed oil and to 3 pounds of dalapon differed significantly from all other treatments. No other differences were significant. $(0=$ no control $; 10=$ complete control. $)$

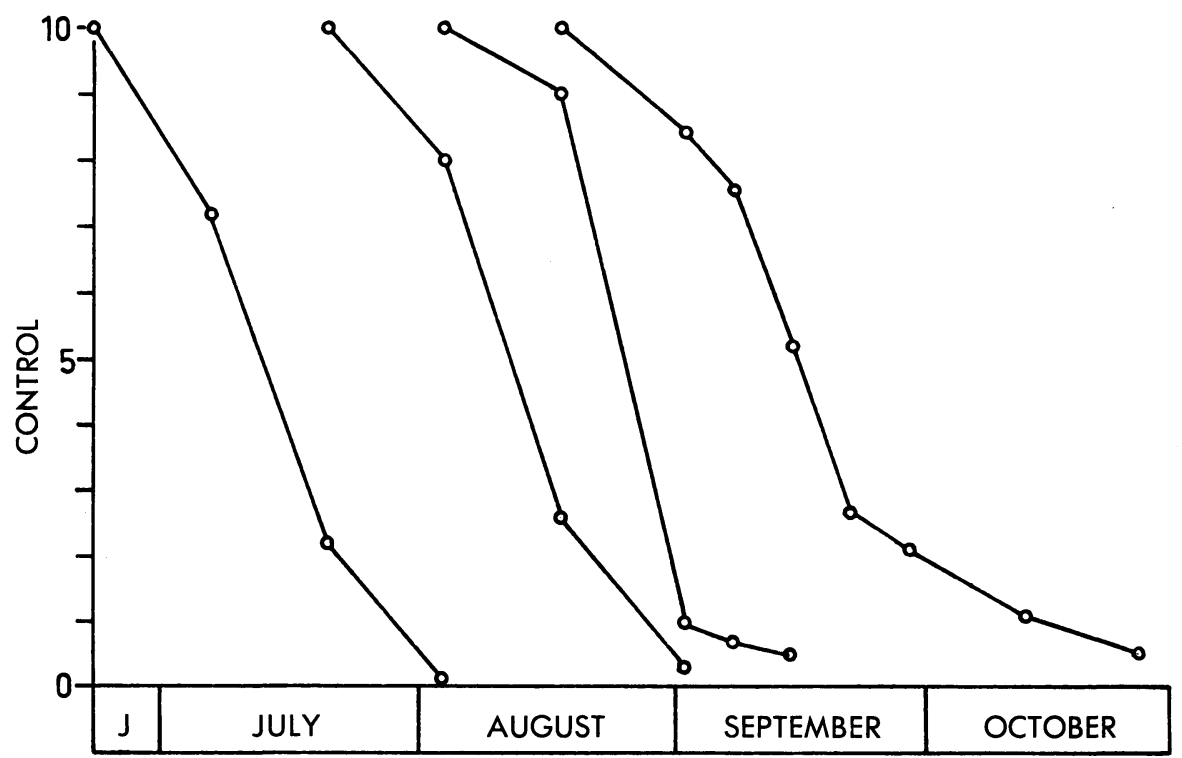

Fig. 2. Effect of season on control of bermudagrass by single applications of aromatic weed oil at 100 gallons per acre. Recovery from injury was most rapid in August and early September, the warmest part of the season. $(0=$ no control $; 10=$ complete control.) 


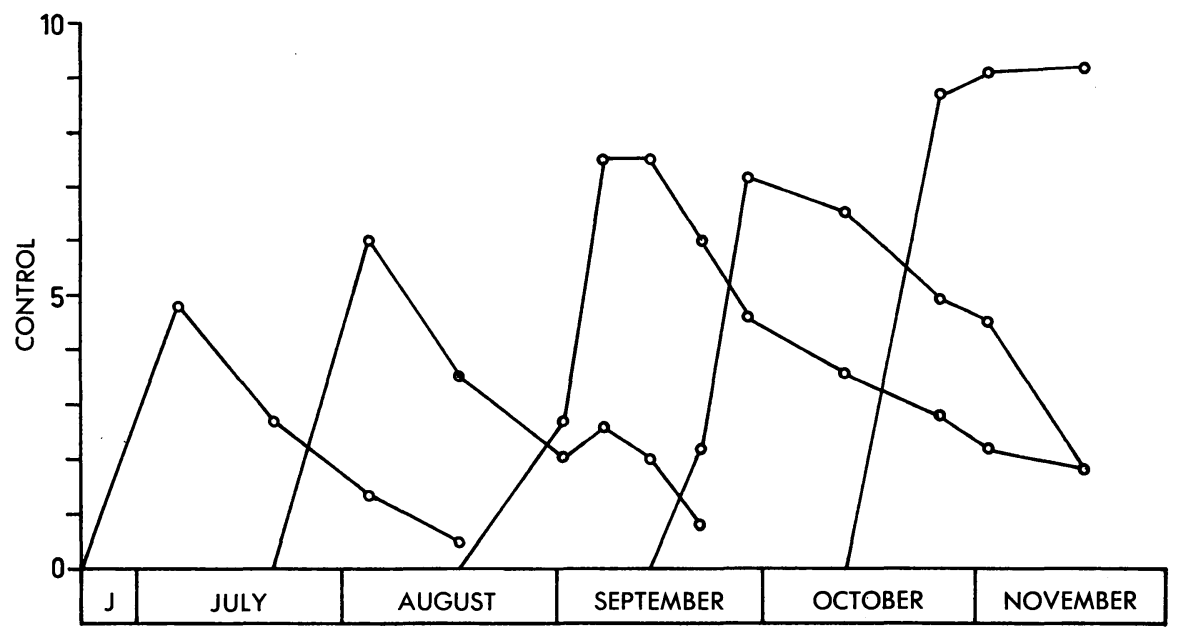

Fig. 3. Effect of season on control of bermudagrass by single applications of dalapon at 4 pounds per acre. Observations were terminated because of frost in November. $(0=$ no control; $10=$ complete control.)

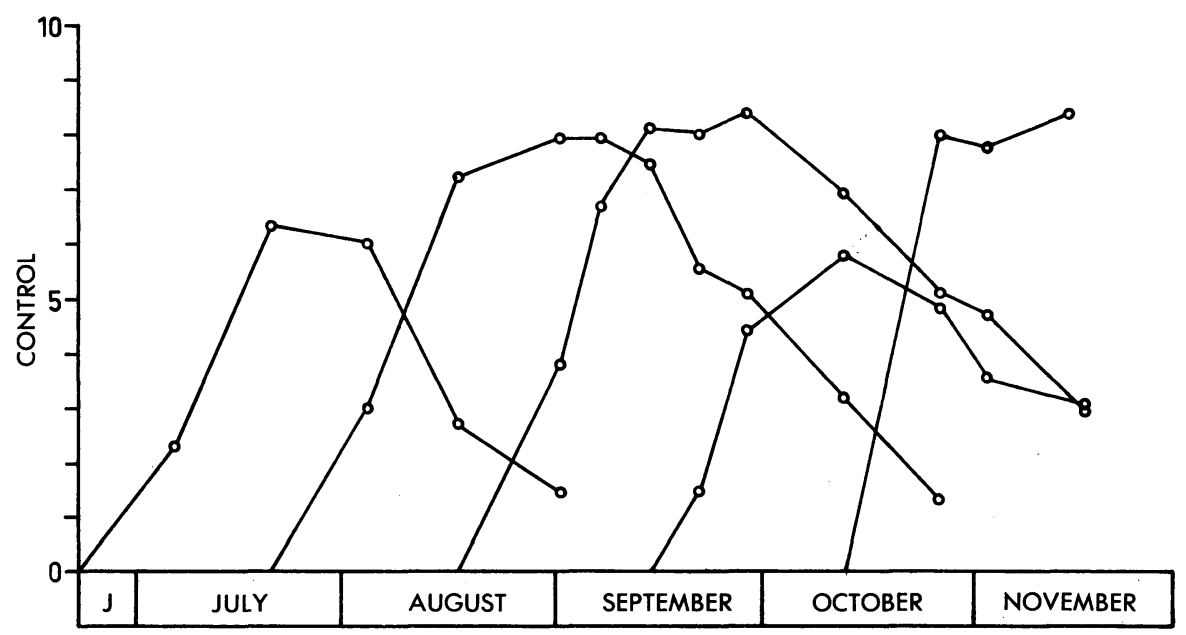

Fig. 4. Effect of season on control of bermudagrass by single applications of amitrole at 4 pounds per acre. $(0=$ no control; $10=$ complete control. $)$

The effect of season on the response of bermudagrass to dalapon is shown in figure 3. With the exception of the mid-September treatment, the trend was toward greater and more lasting effect as the growing season advanced. The variation in September may have been due to temporary environmental factors prevailing at the time of treatment, rather than to long-term seasonal effects. In the case of amitrole (fig. 4), a clear trend of increasing effectiveness was apparent throughout the season. 


\section{Weed Oil}

Table 2 shows the effect of number and frequency of treatments with weed oil. The spray programs consisted of two to six applications at one-week and at two-week intervals, and two to four applications at three-week intervals. Thus, the number of treatments varied from two to six in programs ranging in duration from two to 10 weeks from the first application to the last. Treatments were scheduled so that all programs terminated on the same date, August 30. Data taken seven weeks after the last treatment are plotted in figure 5 on the basis of the total number of treatments in each program. Efficiency increased markedly as time between treatments was increased. Six

TABLE 2

CONTROL OF BERMUDAGRASS BY MULTIPLE TREATMENTS WITH AROMATIC WEED OIL AT 100. GALLONS PER ACRE

\begin{tabular}{|c|c|c|c|c|c|}
\hline \multirow{3}{*}{$\begin{array}{l}\text { Weeks between } \\
\text { applications }\end{array}$} & \multirow{3}{*}{$\begin{array}{l}\text { Number of } \\
\text { applications }\end{array}$} & \multicolumn{4}{|c|}{ Control* } \\
\hline & & \multicolumn{4}{|c|}{ Time after last application } \\
\hline & & 2 weeks & 4 weeks & 7 weeks & 11 weeks \\
\hline 1 & 2 & 8.8 & $6.3 \mathrm{ab}$ & $2.0 \mathrm{w}$ & 0.2 \\
\hline 1 & 3 & 8.6 & $5.8 \mathrm{a}$ & $2.2 \mathrm{w}$ & 0.9 \\
\hline 1 & 4 & 8.7 & $6.6 \mathrm{~b}$ & $2.6 \mathrm{w}$ & 1.4 \\
\hline 1 & 5 & 8.7 & $7.0 \mathrm{bc}$ & $3.0 \mathrm{w}$ & 1.2 \\
\hline 1 & 6 & 8.9 & 7.8 cde & $4.4 \mathrm{x}$ & 2.4 \\
\hline 2 & 2 & 8.9 & $7.1 \mathrm{bcd}$ & $2.7 \mathrm{w}$ & 1.1 \\
\hline 2 & 3 & 9.0 & $7.1 \mathrm{bcd}$ & $2.6 \mathrm{w}$ & 1.6 \\
\hline 2 & 4 & 9.5 & $8.8 \mathrm{gf}$ & $7.2 \mathrm{z}$ & 6.3 \\
\hline 2 & 5 & 9.5 & $8.8 \mathrm{gf}$ & $7.1 \mathrm{y}$ & 6.1 \\
\hline 2 & 6 & 9.7 & $9.4 \mathrm{~g}$ & $8.6 \mathrm{z}$ & 8.7 \\
\hline 2 & 2 & 9.2 & $7.8 \mathrm{de}$ & $3.1 \mathrm{w}$ & 1.4 \\
\hline 3 & 3 & 9.3 & 8.4 ef & $5.6 \mathrm{x}$ & 3.7 \\
\hline 4 & 4 & 9.5 & $9.2 \mathrm{gf}$ & $7.9 \mathrm{yz}$ & 7.2 \\
\hline
\end{tabular}

* $0=$ no control $; 10=$ complete control; averages of eight replicates. Four-week and seven-week data analyzed by the multiple-range test. Statistical groupings $(P=0.05)$ for vertical comparison are shown by letters following the numbers. Values having a letter in common do not differ significantly.

treatments spaced at one-week intervals were about half as effective as the same number of treatments spaced at two-week intervals. Within the range of treatment intervals tested, it is apparent that the control achieved is more a function of duration of the programs than of number of treatments applied. This is shown in figure 6 , in which control is plotted as a function of the duration of the spray program from the first to the last treatment.

\section{Amitrole}

The effect of application rate, spray volume, admixture of kerosene or monuron, and omission of surfactant on the control of bermudagrass with amitrole is shown in table 3. The initial ratings, two weeks after treatment, are not shown in the table. At that time, control was identical for all plots except those treated with the combination of amitrole and monuron. On the basis of 10 as complete control, the plots treated with all rates of amitrole, regardless of the volume of water used in application, or the admixture of kerosene, or the absence of surfactant, were rated at 8.0. All plots treated 


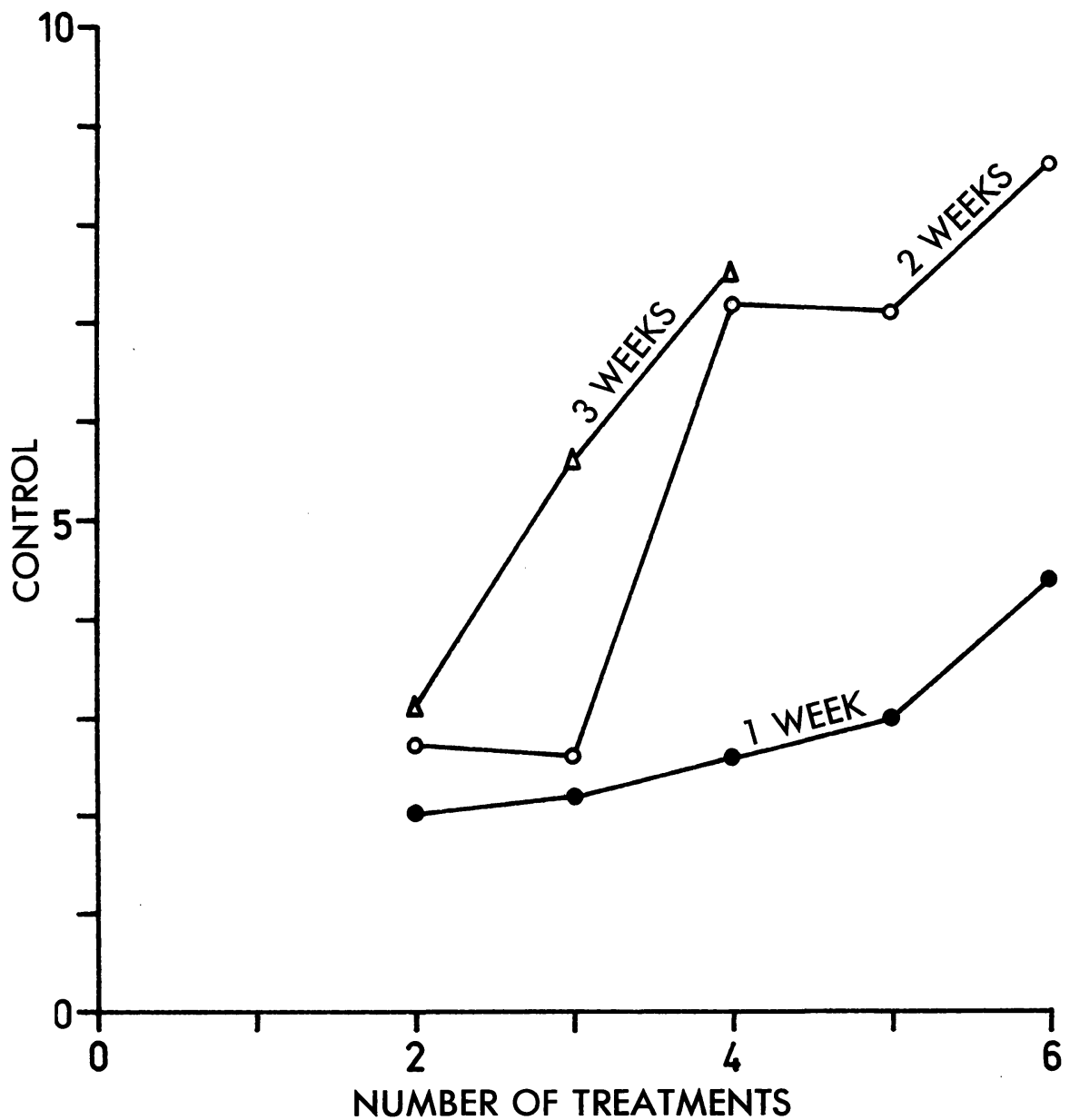

Fig. 5. Effect on control of bermudagrass of number and frequency of sprayings with weed oil at 100 gallons per acre per treatment. Time intervals between sprayings (weeks) are shown for programs of varying numbers of treatments. Data were observed seven weeks after final application of each program. $(0=$ no control; $10=$ complete control. $)$

with the mixture of amitrole and monuron were rated at 9.0 or higher. Initial injury to the grass appeared earlier and was more severe when monuron was included in the spray. The symptoms caused by the mixture were indistinguishable from those caused by amitrole alone. Recovery of the grass and resumption of normal growth were more rapid than in plots treated with the same rates of amitrole alone. The rate of monuron used was insufficient to cause injury to the grass when applied alone. As shown in table 3, forty-five days after treatment the control by the amitrole-monuron mixture containing 4 pounds of amitrole was significantly less than the control achieved by the same rate of amitrole without monuron.

The differential effect of amitrole dosage was not initially apparent, and became evident only during the stage of recovery from injury. The apparent 


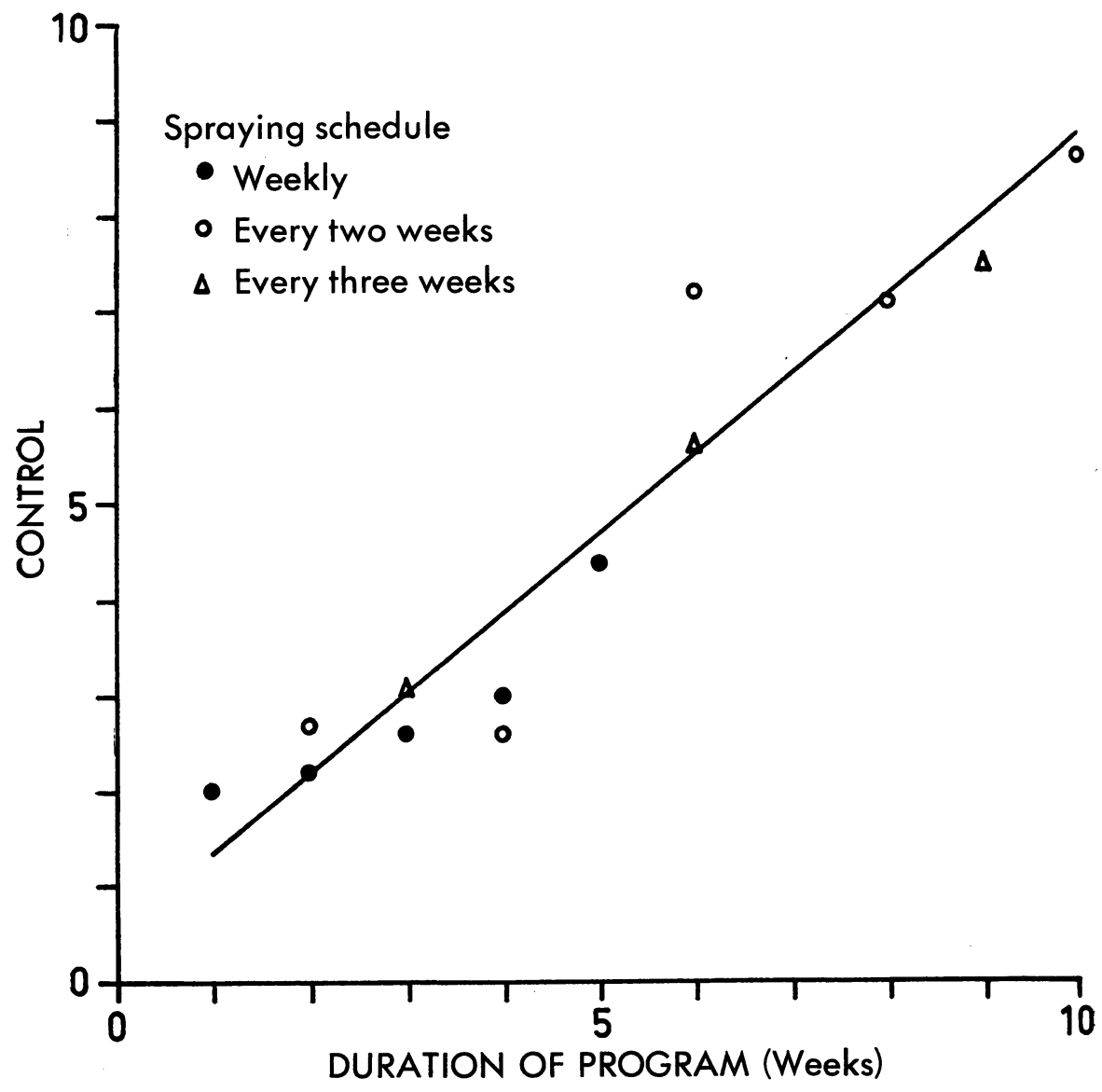

Fig. 6. Control of bermudagrass by multiple applications of aromatic weed oil at 100 gallons per acre. Data observed seven weeks after termination of spray programs. Results of 13 schedules of treatments are plotted on basis of duration of programs from first to last application. Line of best fit was calculated by method of least squares. ( $0=$ no control; $10=$ complete control.)

injury, as judged by discoloration, reached a maximum in about three weeks, regardless of the rate of treatment, spray volume, admixture of kerosene, or omission of surfactant. Differences between dosages first became evident four weeks after treatment. At the 2 pound per acre rate, tissues rapidly recovered and resumed growth. At higher rates, increasing proportions of the foliage and stolons died and were replaced by a sparse growth of albino leaves originating from surviving stolons. Within the range tested, spray volume, admixture of kerosene, and omission of surfactant were without significant effect.

The effect of spray volume on control of bermudagrass by amitrole is shown in table 4. In this experiment a dense stand of grass 8 to 10 inches tall was treated. At the lowest volume, 25 gallons per acre, only superficial wetting of the top foliage was obtained, and the spray dried on the leaves within a few minutes. At the highest rate, 400 gallons per acre, the spray wet into the mat 
TABLE 3

CONTROL OF BERMUDAGRASS BY AMITROLE, AS AFFECTED BY SPRAY VOLUME AND ADDITIVES

\begin{tabular}{|c|c|c|c|c|}
\hline \multirow{3}{*}{ Material } & \multirow{3}{*}{$\begin{array}{l}\text { Application } \\
\text { rate }\end{array}$} & \multirow{3}{*}{ Water } & \multicolumn{2}{|c|}{ Control* $^{*}$} \\
\hline & & & \multicolumn{2}{|c|}{ Time after treatment } \\
\hline & & & 28 days & 45 days \\
\hline & $l b / A$ & $g a l$ & & \\
\hline Amitrole....... & 2 & .100 & $6.2 \mathrm{ab} \dagger$ & $1.6 \mathrm{wx} \dagger$ \\
\hline Amitrole $\ldots \ldots \ldots \ldots \ldots \ldots \ldots \ldots \ldots$ & 4 & 100 & $7.3 \mathrm{bc}$ & $3.7 \mathrm{y}$ \\
\hline Amitrole..$\ldots \ldots \ldots \ldots \ldots \ldots \ldots \ldots \ldots$ & 6 & 100 & $6.9 \mathrm{bc}$ & $2.9 \mathrm{xy}$ \\
\hline Amitrole $\ldots \ldots \ldots \ldots \ldots \ldots \ldots \ldots \ldots$ & 8 & 100 & $7.9 \mathrm{c}$ & $5.4 \mathrm{z}$ \\
\hline Amitrole plus kerosene (1 gal).. & 4 & 99 & $7.0 \mathrm{bc}$ & $2.8 \mathrm{xy}$ \\
\hline Amitrole minus surfactant........ & 4 & 100 & $6.8 \mathrm{bc}$ & $2.3 \mathrm{xy}$ \\
\hline Amitrole plus monuron $(1.6 \mathrm{lb}) \ldots$ & 4 & 100 & $6.2 \mathrm{ab}$ & $0.8 \mathrm{w}$ \\
\hline Amitrole plus monuron $(1.6 \mathrm{lb}) \ldots$ & 2 & 100 & $5.6 \mathrm{a}$ & $0.8 \mathrm{w}$ \\
\hline Amitrole $\ldots \ldots \ldots \ldots \ldots \ldots \ldots$ & 4 & 50 & $7.3 \mathrm{bc}$ & $2.7 \mathrm{xy}$ \\
\hline Amitrole....... & 4 & 150 & $7.4 \mathrm{c}$ & $2.6 \mathrm{xy}$ \\
\hline Amitrole....... & 4 & 200 & $7.2 \mathrm{bc}$ & $2.4 \mathrm{xy}$ \\
\hline
\end{tabular}

$* 0=$ no control $; 10=$ complete control.

† Letters indicate statistical populations for vertical comparisons at the 5 per cent level. Mean values not followed by a common letter are statistically different.

of grass thoroughly for several inches, but without runoff. As shown by Day and Jordan (1961), dense stands of bermudagrass can retain volumes of spray in excess of 500 gallons per acre without runoff. As in the previous experiment (table 3 ), within the range tested, no significant effect of spray volume on the control of bermudagrass by amitrole was observed.

The effect of split applications of amitrole on bermudagrass was studied. The objectives were to determine (1) optimum long-term spray programs from the standpoint of efficient control of the grass, and (2) methods for keeping the dosage applied at any one time at a low level in order to secure the maximum margin of safety for orchard trees. Table 5 shows the control

TABLE 4

CONTROL OF BERMUDAGRASS FOLLOWING TREATMENT WITH AMITROLE IN VARYING VOLUMES OF WATER

\begin{tabular}{|c|c|c|c|c|c|}
\hline \multirow{3}{*}{ Material } & \multirow{3}{*}{$\begin{array}{l}\text { Application } \\
\text { rate }\end{array}$} & \multirow{3}{*}{$\begin{array}{l}\text { Volume of } \\
\text { water }\end{array}$} & \multicolumn{3}{|c|}{ Control* } \\
\hline & & & \multicolumn{3}{|c|}{ Time from treatment to rating } \\
\hline & & & 14 days & 21 days & 48 days \\
\hline Amitrole.... & 8 & 25 & $4.7 \dagger$ & $8.1 \dagger$ & $9.7 \dagger$ \\
\hline Amitrole... & 8 & 50 & 5.5 & 8.6 & 9.3 \\
\hline Amitrole...... & 8 & 100 & 5.4 & 8.4 & 9.7 \\
\hline Amitrole.......... & 8 & 200 & 4.8 & 8.3 & 9.1 \\
\hline Amitrole $\ldots . \ldots \ldots \ldots \ldots \ldots$ & 8 & 400 & 4.9 & 8.2 & 9.6 \\
\hline
\end{tabular}

* $0=$ no control; $10=$ complete control.

$\dagger$ No differences among mean values on the same dates of observation are significant. 
TABLE 5

CONTROL* OF BERMUDAGRASS BY TWO SUCCESSIVE TREATMENTS WITH AMITROLE AT 4 POUNDS PER ACRE WITH VARYING TIME BETWEEN TREATMENTS

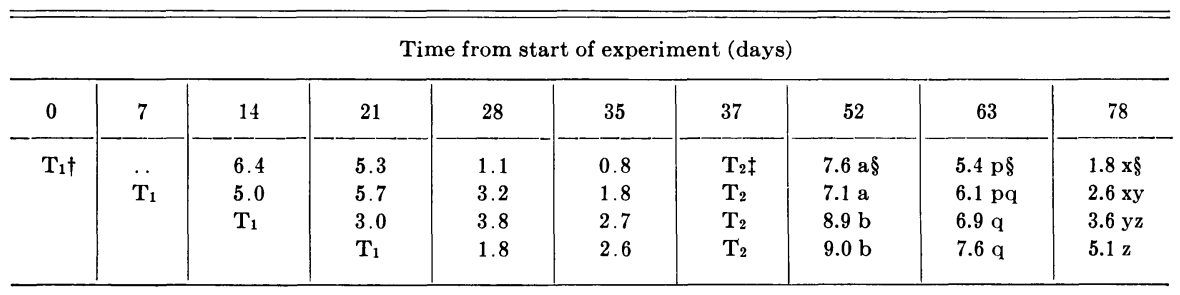

* $0=$ no control; $10=$ complete control.

$+\mathrm{T}_{1}=$ first treatment.

$\ddagger T_{2}=$ second treatment.
$\S$ Letters indicate statistical populations for vertical comparisons at the 5 per cent level. Mean values not followed by a common letter are statistically different.

obtained from two successive applications of amitrole at 4 pounds per acre, applied at intervals between initial and second treatments of 16 to 37 days. The initial treatments were applied $0,7,14$, and 21 days from the beginning of the experiment. The second treatments were applied on the thirty-seventh day. Effectiveness tended to increase as time between treatments was decreased.

Data from a similar experiment are shown in figure 7 in which the control of bermudagrass by one application of 12 pounds of amitrole per acre and two applications of 6 pounds per acre each, spaced three, six, and nine weeks apart are compared. In this experiment, final treatments were applied on August 31. As a result of the higher rates of application and enhanced effect of amitrole late in the season, excellent control was obtained from all treatments. The single 12 pounds per acre treatment was rated numerically somewhat more effective than the split treatments, but not significantly so.

\section{Combinations of Amitrole and Weed Oil}

The feasibility of combining amitrole and weed-oil treatments into spray programs was tested. One objective was to secure a major portion of the control with an initial application of amitrole followed by control of the regrowth with weed oil, thus reducing the total amount of amitrole applied in the orchard. The effect of amitrole at 6 pounds per acre, followed by aromatic weed oil three weeks later, was compared with the effect of amitrole alone and of oil alone (fig. 8). The oil was applied somewhat before maximum injury from the amitrole had occurred, and resulted in reduced control. Programs in which the oil was applied first were also tested. The effect of weed oil followed by amitrole is shown in figure 9 . Applications were spaced 0 , two, four, and eight weeks apart. In the 0 spacing of applications, oil was applied first, followed within a few minutes by amitrole. In this case, the response of the grass was the same as from a treatment with oil alone. The control obtained increased progressively as the time between treatments of oil and amitrole was extended, becoming essentially the same for the eight-weeks' spacing as that for amitrole not preceded by an oil treatment. As long as any appreciable 


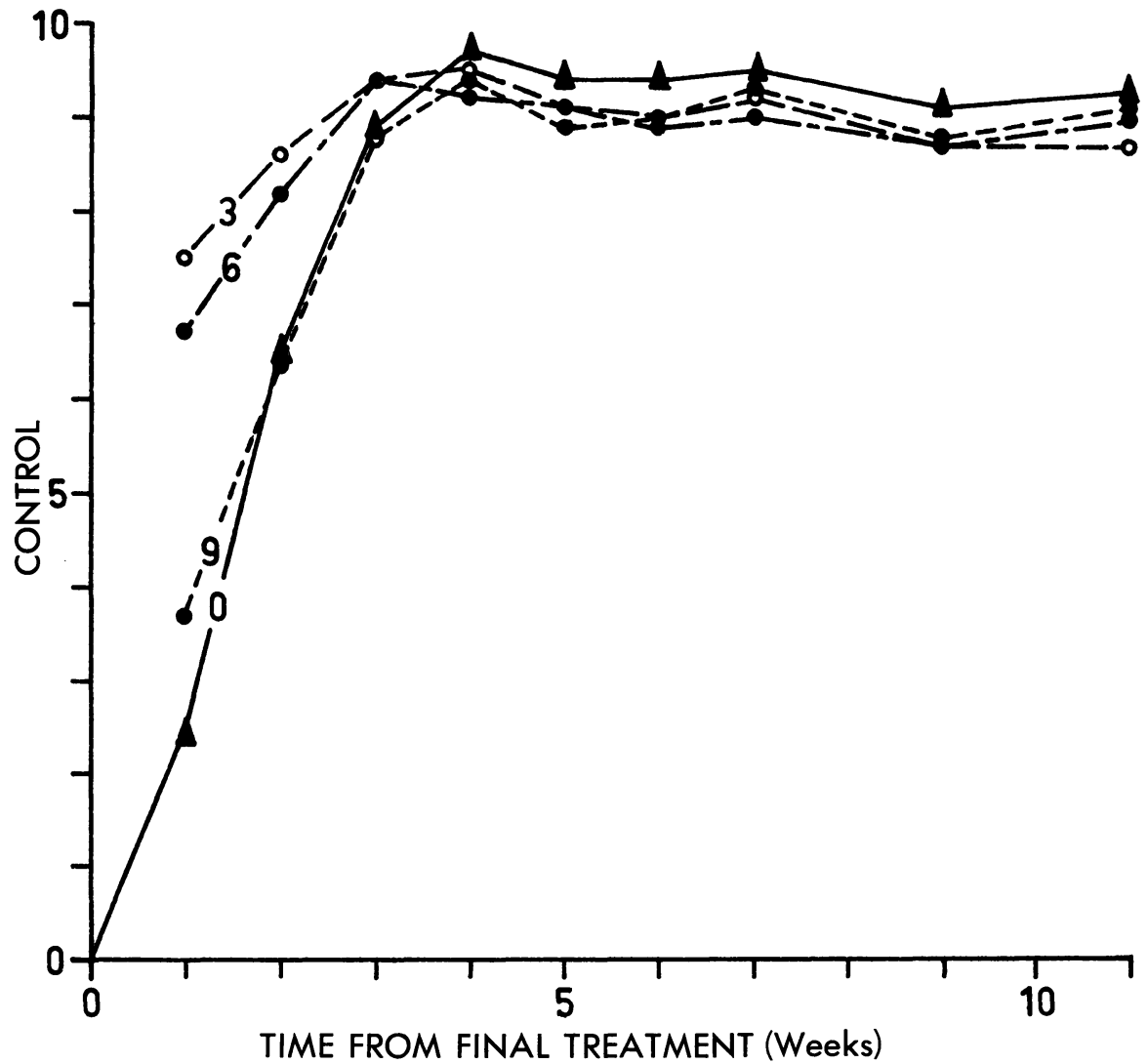

Fig. 7. Control of bermudagrass by a single application of amitrole at 12 pounds per acre (0) as compared with two treatments at 6 pounds per acre, each spaced at intervals of three, six, and nine weeks. Differences subsequent to second-week observations are not significant. $(0=$ no control $; 10=$ complete control. $)$

effect of the oil remained at the time of amitrole application, less control was obtained. These results appear reasonable in view of the action of amitrole as a foliar-absorbed, translocated herbicide. The greatest effect from amitrole would be expected when the underground parts of the plant are connected to uninjured foliage by the most direct routes.

\section{Combinations of Amitrole and Dalapon}

The effect of combination treatments of amitrole and dalapon on bermudagrass is shown in table 6 . Amitrole at the rate of 4 pounds per acre was tested in combination with dalapon at rates of 3 and 6 pounds per acre, and com. pared with the effects obtained with the same rates of each herbicide alone.

Initially, the combination of 4 pounds of amitrole and 6 pounds of dalapon per acre resulted in significantly greater apparent injury to the grass than did the 6-pound rate of dalapon without amitrole. Dalapon at 3 pounds per acre was initially less effective than any of the other treatments. After nine weeks the control by 3 pounds and 6 pounds per acre of dalapon was higher than that obtained when the same rates were combined with 4 pounds per acre 


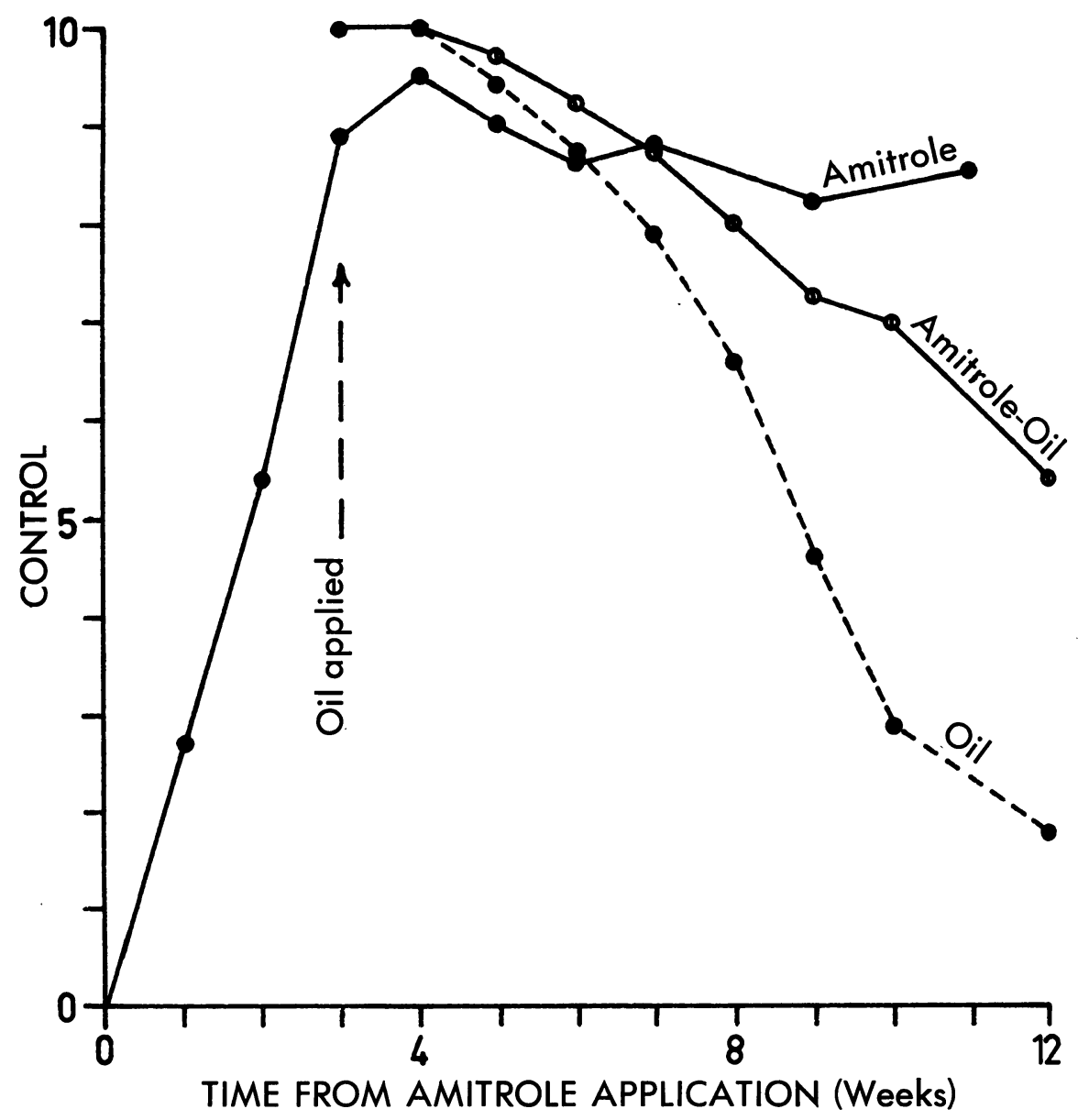

Fig. 8. Comparison of control of bermudagrass by: (1) aromatic weed oil at 100 gallons per acre, applied three weeks after treatment with amitrole at 6 pounds per acre; (2) amitrole not followed by oil; (3) oil not preceded by amitrole. $(0=$ no control; $10=$ com. plete control.)

of amitrole although not quite significantly at the lower rate of dalapon. Dalapon at both rates gave a higher long-term control of the grass than did the amitrole treatment. The combination treatments were intermediate in effectiveness. The herbicidal effects of amitrole and dalapon on bermudagrass are thus shown to be incompatible.

\section{Dalapon}

A number of spray programs based on repeated use of dalapon at 3 and 6 pounds per acre were tested. Figure 10 shows the results obtained by multiple treatments of bermudagrass with dalapon at 3 pounds per acre, spaced one, two, four, and eight weeks apart, as compared with single treatments at 3 pounds and 6 pounds, respectively. Differences at the four-, seven-, and 11- 


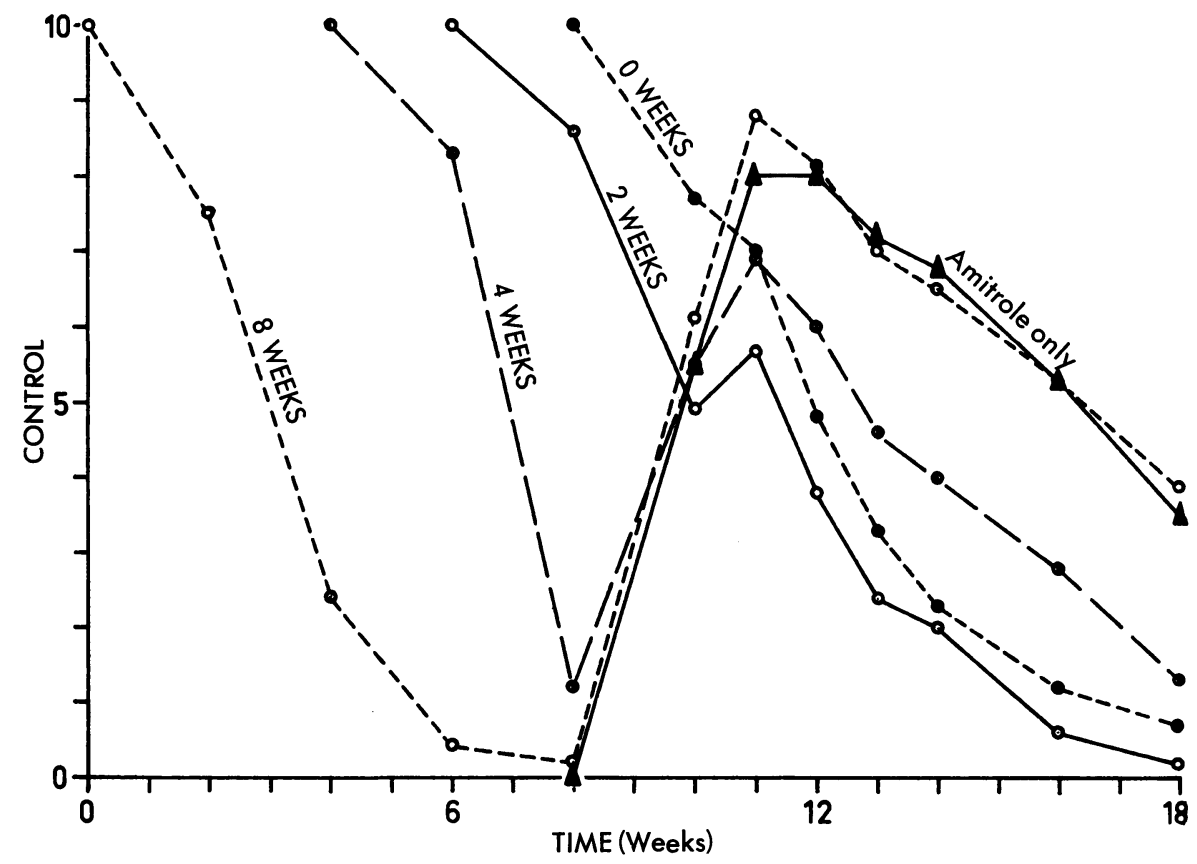

Fig. 9. Comparison of control of bermudagrass by: (1) weed oil at 100 gallons per acre followed immediately ( $0 \mathrm{wks})$, and at two, four, and eight weeks by amitrole at 6 pounds; (2) amitrole at the same rate, not preceded by weed oil. Amitrole was applied to all plots eight weeks after start of the experiment (see horizontal axis). Effects shown at left of the eight-week point are result of pretreatment with oil. $(0=$ no control; $10=$ complete control.)

TABLE 6

CONTROL* OF BERMUDAGRASS FOLLOWING SEPARATE AND COMBINATION TREATMENTS WITH AMITROLE AND DALAPON

\begin{tabular}{c|c|c|c|c|c}
\hline \hline Material and rate of application & \multicolumn{3}{|c}{ Time from treatment to rating } \\
\cline { 1 - 5 } Amitrole & Dalapon & 2 weeks & 3 weeks & 5 weeks & 9 weeks \\
\hline$l b / A$ & $l b / A$ & & & & \\
4 & 0 & $7.2 \mathrm{bc} \dagger$ & $7.5 \mathrm{mn} \dagger$ & $1.6 \mathrm{p} \dagger$ & $1.6 \mathrm{x} \dagger$ \\
4 & 3 & $8.4 \mathrm{bc}$ & $9.1 \mathrm{n}$ & $6.9 \mathrm{pq}$ & $3.6 \mathrm{xy}$ \\
4 & 6 & $8.8 \mathrm{c}$ & $8.9 \mathrm{n}$ & $7.1 \mathrm{pq}$ & $4.1 \mathrm{xy}$ \\
0 & 3 & $4.4 \mathrm{a}$ & $6.4 \mathrm{~m}$ & $5.6 \mathrm{q}$ & $5.3 \mathrm{yz}$ \\
0 & 6 & $6.8 \mathrm{~b}$ & $8.1 \mathrm{n}$ & $8.2 \mathrm{v}$ & $7.8 \mathrm{z}$ \\
\hline
\end{tabular}

* 0 = no control; $10=$ complete control.

$\dagger$ Letters indicate statistical populations for vertical comparisons at the 5 per cent level. Mean values not followed by a common letter are statistically different.

week observations were tested for significance $(P=0.05)$. The single 6-pound treatment, and all multiple treatments with 3 pounds, were significantly more effective than was the single application at 3 pounds. The treatments spaced one, two, and eight weeks apart gave somewhat better results than did those 


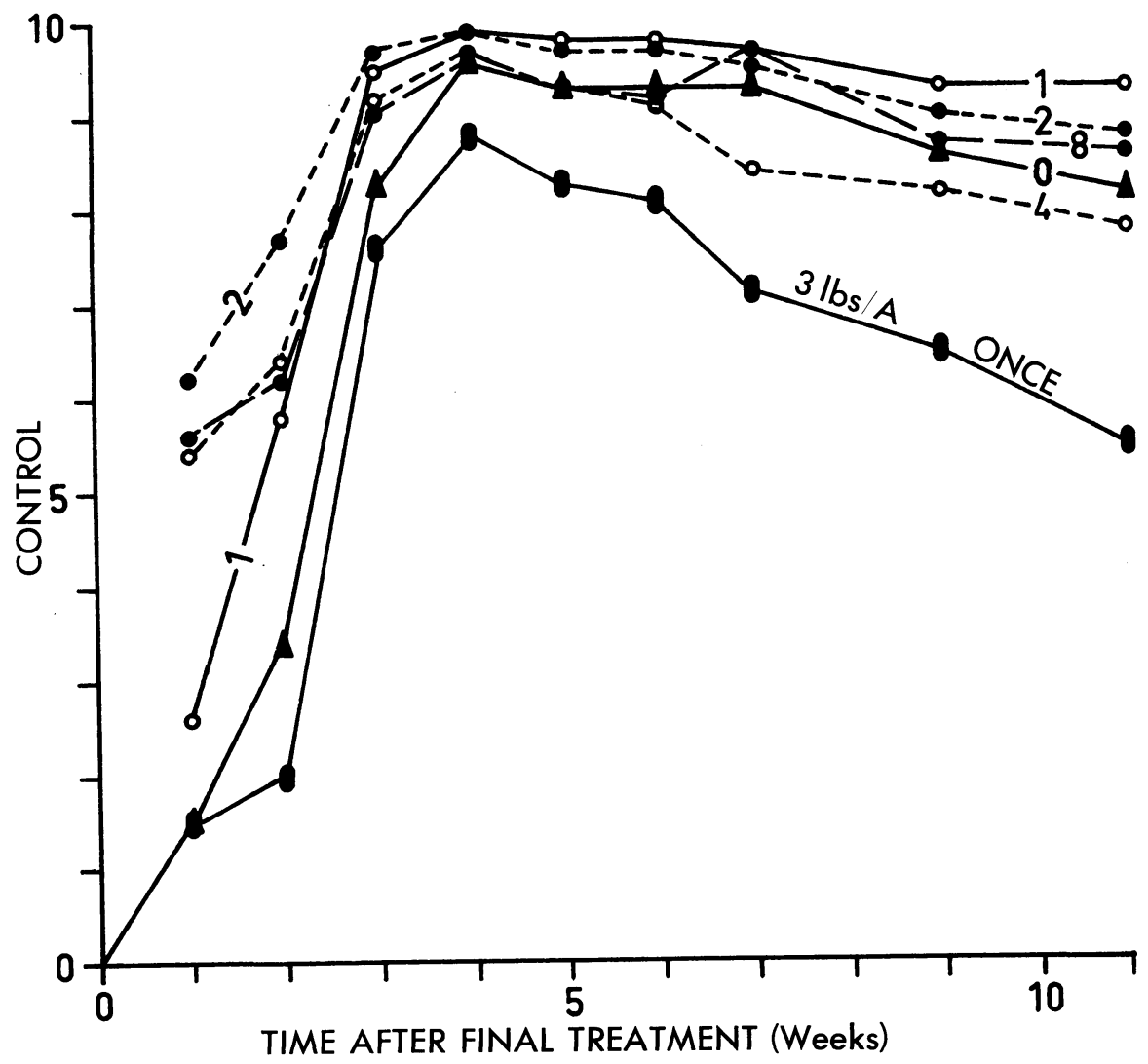

Fig. 10. Comparison of control of bermudagrass by: (1) a single application of dalapon at 3 pounds per acre; (2) two applications at 3 pounds per acre, each spaced at one, two, four, and eight weeks; (3) a single application at 6 pounds per acre (curve marked 0 ). $(0=$ no control $; 10=$ complete control. $)$

at 0 and four weeks, although not significantly so on all observation dates. At the seven- and 11-week observations, the one-week interval between treatments had resulted in significantly better control than had the four-week interval. The reduced control by treatments spaced four weeks apart may have resulted because the second application was made at the time of maximum injury from the first application. At that time most of the top foliage was dead; thus, foliar absorption was necessarily limited.

Figure 11 shows the results obtained from two applications of dalapon at the rate of 6 pounds per acre, spaced one, two, three, four, six, and eight weeks apart, as compared with a single application at 12 pounds per acre. Differences among treatments at the four-, seven-, and 11-week observations were tested for significance $(P=0.05)$. The only significant difference occurred between the two- and eight-week spacings at the 11-week observations.

In this experiment, as with the lower rate, the split treatments were highly 


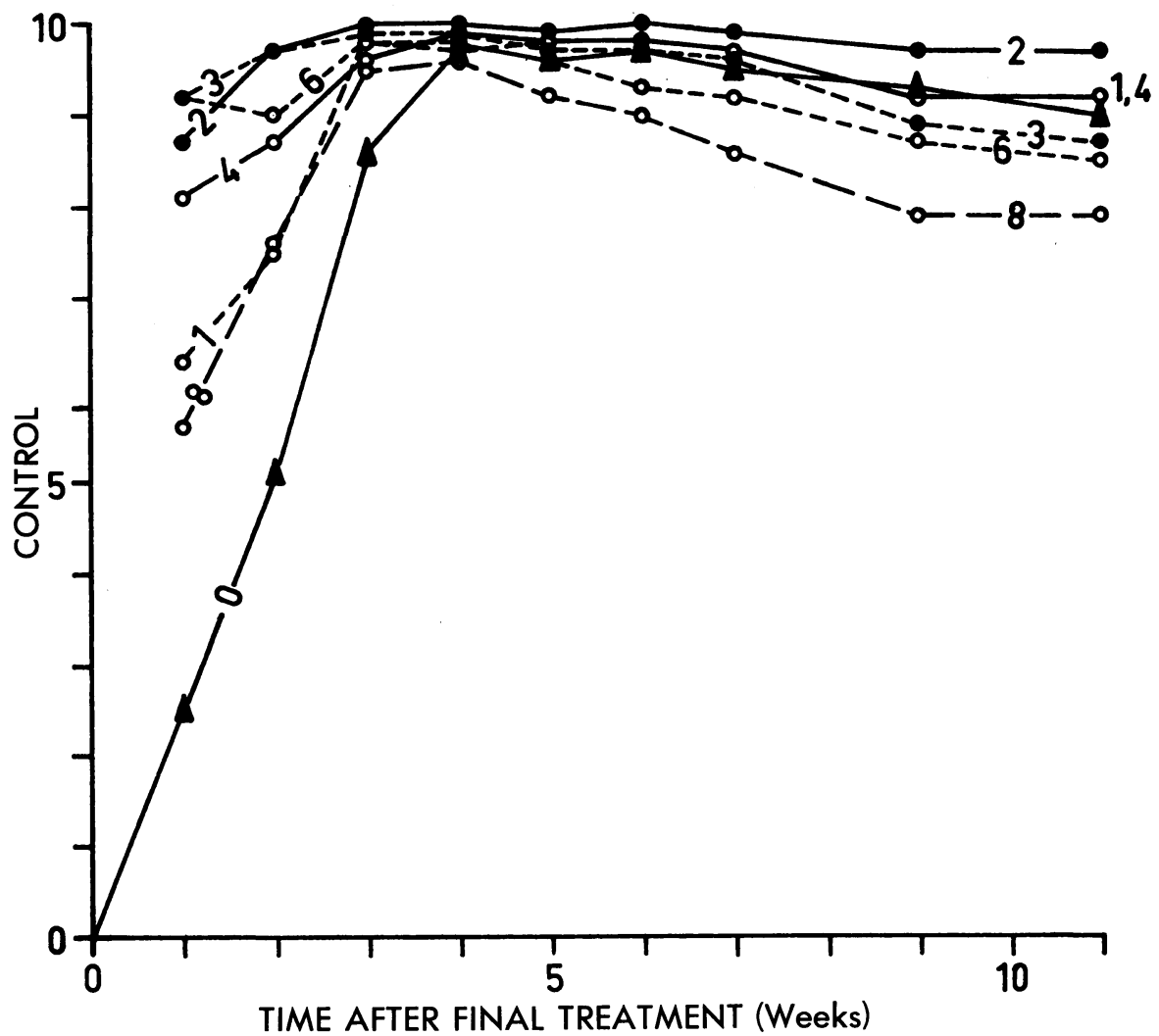

Fig. 11. Comparison of control of bermudagrass by: (1) two successive applications of dalapon at 6 pounds per acre, each spaced at one, two, three, four, six, and eight weeks; (2) a single application at 12 pounds per acre (curve marked 0$).(0=$ no control; $10=\mathrm{com}$ plete control.)

effective, and could serve as a suitable replacement for a single treatment with the same total amount of herbicide.

Figure 12 shows results from programs of three applications of dalapon at 3 pounds per acre, spaced one, two, and four weeks apart, as compared with a single application of 9 pounds per acre. None of the differences at the four-, seven-, or 11-week observations was significant.

From this and the preceding experiment, it is concluded that a given dosage of dalapon can be split into individual treatments applied over a wide range of schedules without reduction in effectiveness.

In addition, it was observed throughout the experiments that dalapon was more effective on lush, vigorous grass than on grass that was growing slowly, particularly as a result of drought.

\section{Combinations of Dalapon and Weed Oil}

Weed-oil and dalapon treatments were combined to determine the feasibility of controlling the major portion of the grass with a minimum application of 


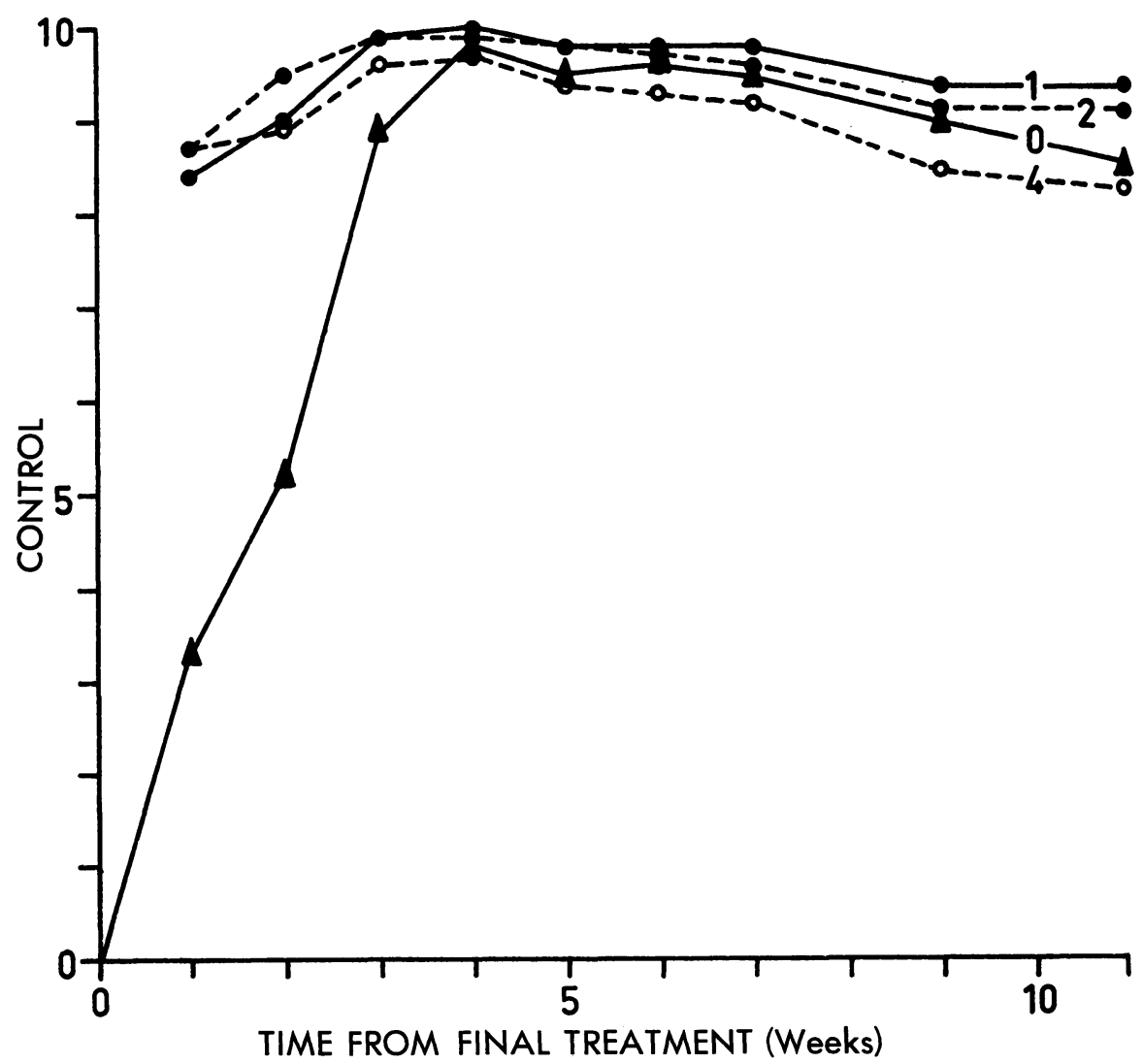

Fig. 12. Control of bermudagrass by a single application of dalapon at 9 pounds per acre $(0)$ as compared with three successive treatments at 3 pounds per acre, each spaced at one, two, and four weeks. No differences are significant. $(0=$ no control $; 10=$ complete control.)

dalapon followed by clean-up of the regrowth with weed oil. Figure 13 shows the control obtained by applications of dalapon at the rate of 6 pounds per acre, followed in one, three, or six weeks by top kill with weed oil at the rate of 100 gallons per acre. In all cases, the follow-up application of oil adversely affected the action of dalapon.

Control of bermudagrass by weed oil followed immediately and at two, four, and eight weeks by 6 pounds per acre of dalapon was compared with control by 6 pounds of dalapon per acre without prior oil treatment (fig. 14). As with amitrole, prior treatment with weed oil lowered control in those cases in which an appreciable effect of the oil remained when dalapon was applied.

\section{DISCUSSION}

In the screening of various herbicides for bermudagrass control, none was found which adequately controlled the grass at dosages likely to be safe to 


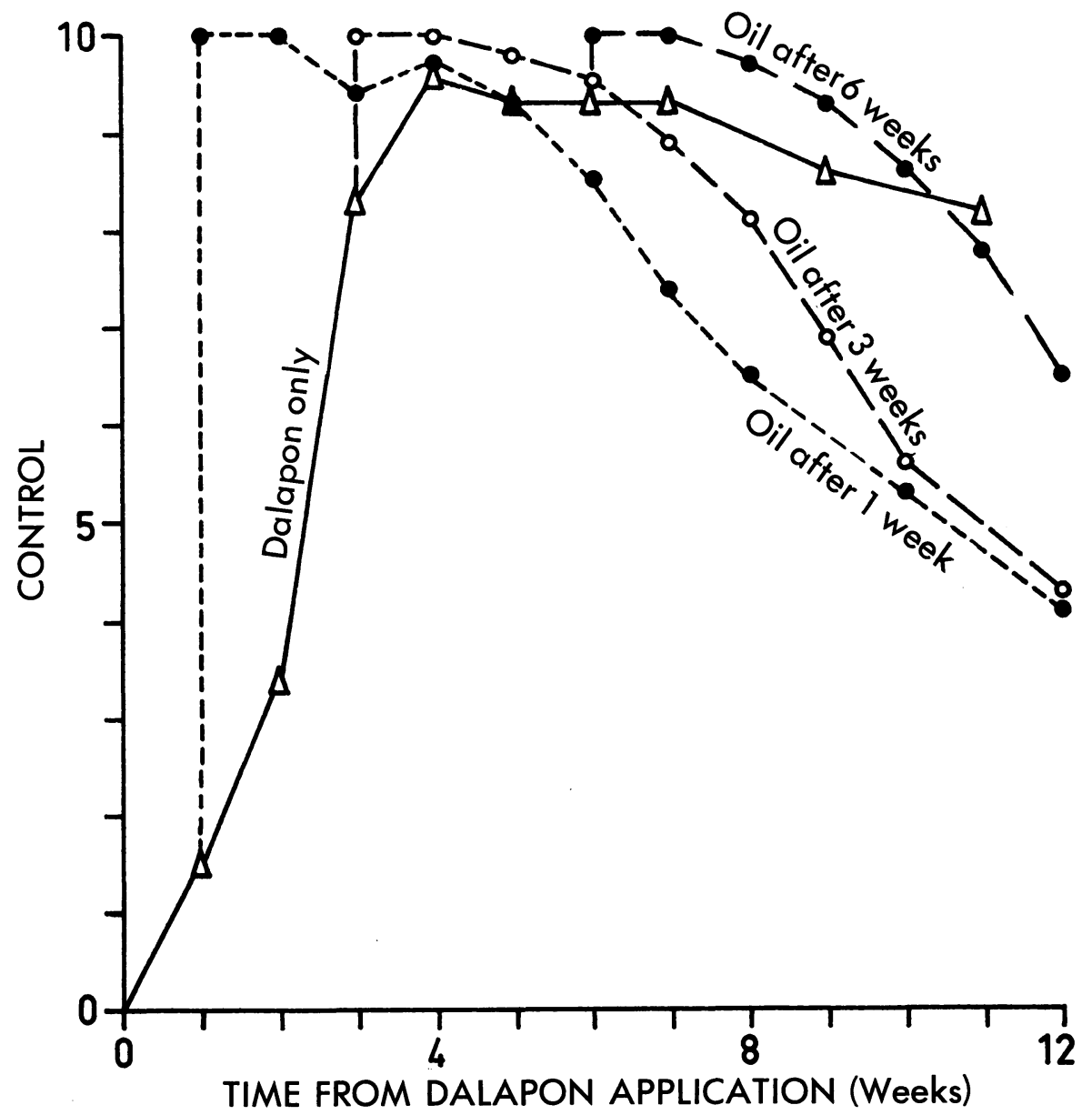

Fig. 13. Effect of spraying bermudagrass with aromatic weed oil at 100 gallons per acre, one, three, and six weeks after application of dalapon at 6 pounds per acre. $(0=$ no control; $10=$ complete control.)

use in citrus orchards. Some of the herbicides tested had little or no effect on the grass. Diquat showed severe contact injury to the foliage, but the grass rapidly recovered. Atratone and prometone controlled the grass and had long residual effects, but the required dosages were probably too high for safe use in eitrus. The possibility of using spray programs based on repeated applications or combinations of these herbicides at low dosages should be considered. Combinations of the better contact herbicides and those with long residual effect, through root absorption, should be studied in an attempt to reduce the dosages of the latter to levels the trees can tolerate.

The recovery of bermudagrass from late-season treatments with weed oil, amitrole, or dalapon was slow because growth is less vigorous in the fall than in late spring or summer. 
Weed oil was more effective in controlling bermudagrass as the time between treatments was increased from one- to three-week intervals. Weed oil is a contact herbicide that destroys the foliage and runners. Apparently the roots and rhizomes are killed if the program is continued long enough to deplete the food reserves. Most efficient control can be expected if successive treatments are made when reserves are at a minimum and before they are replenished by the products of photosynthesis from the newly-developing

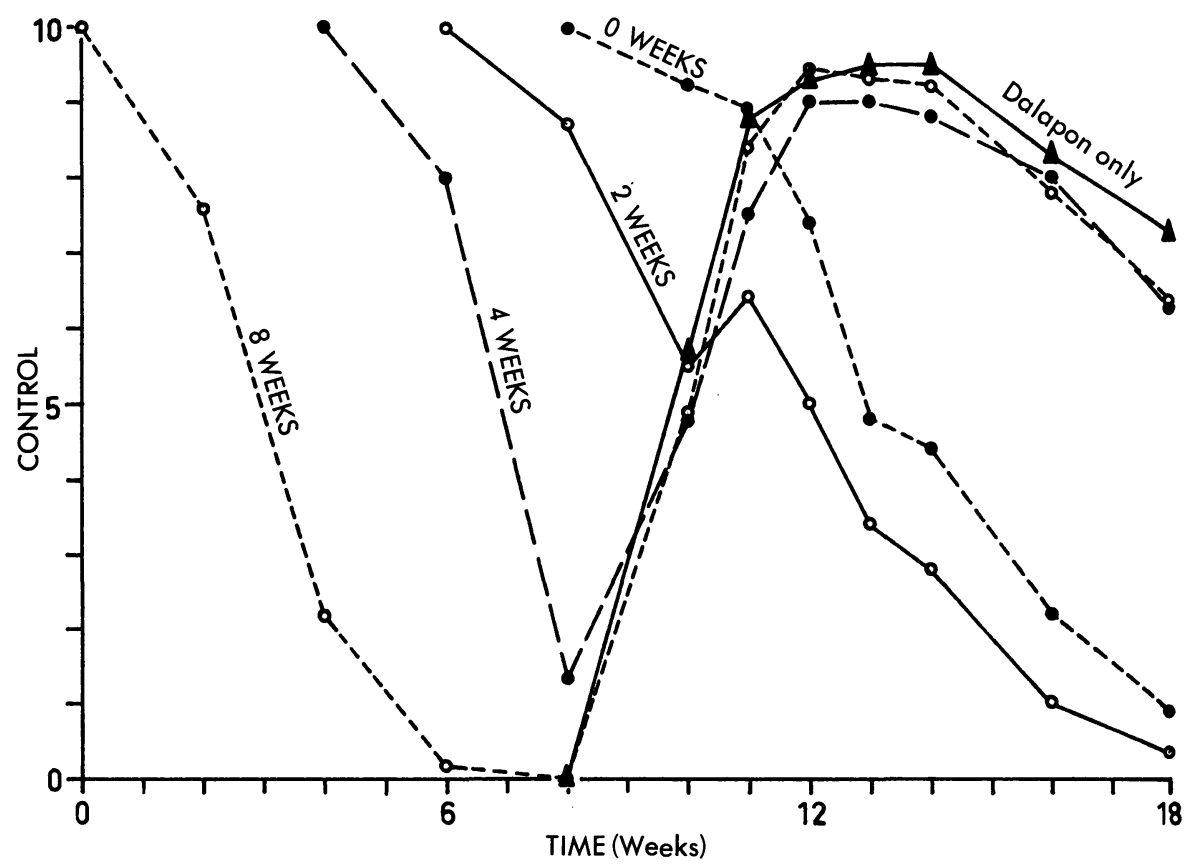

Fig. 14. Comparison of control of bermudagrass by: (1) weed oil at 100 gallons per acre followed immediately ( $0 \mathrm{wks})$ and at two, four, and eight weeks by dalapon at 6 pounds per acre; (2) dalapon at 6 pounds per acre without prior oil spray. $(0=$ no control; $10=$ complete control.)

foliage. Evidently the optimum spacing of treatments for most rapid depletion of food reserves, under the conditions of the experiment, was three or more weeks. The duration of the program would be expected to depend on the level of food reserves in the grass at the beginning of the spray program. As the program progressed, only persistent spots or plants would require treatment, thus reducing the amount of oil per treatment.

Spray volume, admixture of kerosene, or omission of surfactant had no significant effect on the control of bermudagrass with amitrole. Increased volume and inclusion of surfactant in the spray mixture visibly improved the distribution of the amitrole spray over the foliage, yet the herbicidal effects of amitrole were not altered. Evidently spray distribution was not a major limiting factor in the action of amitrole. The total spray dosage is the important variable in the control of bermudagrass with amitrole. A single massive dose is more effective than closely spaced, multiple applications. 
Applications of weed oil before or after amitrole or dalapon treatments did not enhance the control with either material. Pretreatment with oil was either deleterious to the effect of a succeeding treatment with dalapon or amitrole or without significant effect; it was never beneficial. The herbicidal action of amitrole is not dependent in a simple way on the depletion of food reserves but appears to be related to the way food reserves are mobilized and shifted about in the plant in response to spray programs and management practices before and after application of amitrole. Reduction of food reserves by previous treatment with weed oil failed to enhance the effectiveness of subsequent treatments with amitrole. This seems reasonable in view of the findings of Crafts and Yamaguchi (1958) that amitrole translocation is correlated with the movement of food from leaves. Young foliage rapidly regrowing following weed-oil treatment draws on food reserves rather than returning food to the roots and rhizomes. Reduced effectiveness of amitrole following oil spraying could be explained on the basis of reduced downward translocation.

Addition of monuron to amitrole sprays or addition of amitrole to dalapon sprays increased initial foliar injury symptoms but decreased the long-term level of control below that by amitrole or dalapon alone. The initial high level of injury caused by these mixtures may have interfered with the slower translocation processes needed to carry the herbicides to underground plant parts.

The observation that amitrole is not translocated from chlorotic leaves (Crafts and Yamaguchi, 1958) could also explain the limited effectiveness of multiple treatments with amitrole. Plants made chlorotic by the first treatment might be expected to fail to translocate amitrole applied in a second treatment.

Monuron, through its inhibition of photosynthesis (Wessels and van der Veen, 1956), may function in the same way. When monuron and amitrole are applied at the same time, less photosynthate is available to be translocated from the leaves, and therefore correspondingly less amitrole. The amitrole is retained in the leaves, causing more rapid and more pronounced initial chlorosis, and less herbicidal action on the roots and rhizomes.

Dalapon is more effective than amitrole for control of bermudagrass in early and middle season; the materials are about equal in effectiveness in late season. The general pattern of development of greatest injury and the time factors for regrowth are similar for the two herbicides. The seasonal pattern of effectiveness, as well as the cost factor, favors the use of dalapon for bermudagrass control. As with amitrole, a single treatment with dalapon at low dosages does not eradicate bermudagrass. This can be achieved only after a program of re-treatment by successive applications of dalapon either alone or combined with other herbicides.

For orchard use, there is less risk of tree injury from long-term, low-dosage spray programs than from single, massive applications (Kretchman, 1961). Repeated applications of low dosages may keep an injurious amount of herbicide from leaching into the root zone of the trees. Presumably all or most of the soil residue from a treatment would be decomposed before a subsequent treatment is applied (Thiegs, 1955), thus reducing the peak concentration available in the soil at any one time. Split applications of 3 pounds per acre 
are as effective as single applications of 6 or 9 pounds per acre, and split applications of 6 pounds per acre are as effective as single applications of 12 pounds. Three applications at 3 pounds per acre, spaced eight weeks apart, would be expected to provide season-long control of bermudagrass with minimum risk to citrus trees.

Field experience has shown that citrus orchards are often injured by general applications of dalapon at rates above 6 pounds per acre, and occasionally at rates as low as 3 pounds. Kretchman (1961) reports symptoms of dalapon injury to citrus at similar rates in Florida. The amount of injury depends upon local soil and weather conditions.

\section{SUMMARY}

A number of herbicides were screened for herbicidal action on bermudagrass (Cynodon dactylon (L.) Pers.) in California citrus orchards. Spray programs tested included use of petroleum oil, amitrole, and dalapon alone, combined with one another, and combined with other herbicides. Atratone and prometone at 10 or more pounds per acre effectively controlled bermudagrass. Ipazine, trietazine, simetone, simazine, CIPC, EPTC, and maleic hydrazide were not highly herbicidal. Sodium 2,3-dichloroisobutyrate, a dalapon analogue, was one-eighth as effective as dalapon. Spray programs based on applications of weed oil, amitrole, and dalapon were highly effective. Spraying with weed oil at three-week intervals was as effective as spraying at more frequent intervals. Amitrole was more effective late in the growing season. This was also true of dalapon, but to a lesser extent. Variations in spraying volume, presence or absence of surfactant, and admixture of small amounts of kerosene were without appreciable effect on the action of amitrole. Inclusion of small amounts of monuron in amitrole sprays reduced phytotoxicity. Mixtures of amitrole and dalapon were less toxic than the same rates of dalapon alone. In multiple applications of amitrole, effectiveness increased as the time between applications was decreased. A single application was more effective than split treatments employing the same total amount of herbicide.

Prior or subsequent treatment with weed oil reduced the herbicidal effectiveness of applications of amitrole or dalapon over a wide range of timings between applications.

Multiple treatments with low dosages of dalapon were equal to or superior to single sprayings with the same total amount of herbicide provided applications were spaced to avoid spraying when all top growth of the grass had been killed by previous treatments.

A spray program of three applications of dalapon per growing season, at the rate of 3 pounds per acre at eight-week intervals, is considered a reasonable compromise among the factors of cost, effectiveness, and minimum risk of tree injury from spray residues. 


\section{LITERATURE CITED}

BurT, E. O., and J. T. McCown

1959. Controlling perennial grasses in citrus orchards. Proc. 12th Southern Weed Conf. 93-99. (Mimeo.)

Crafts, A. S., and S. YAMAguchi

1958. Comparative tests on the uptake and distribution of labeled herbicides by Zebrina pendula and Tradescantia fluminensis. Hilgardia 27 (16):421-54.

DAY, Boysie E.

1955. Urea herbicides for citrus weed control. Calif. Citrogr. 40: 398, 408, 410, 412.

1957. The bermudagrass problem in citrus and avocado orchards. Proc. Ninth Ann. Calif. Weed Conf.: 22-25. (Mimeo.)

1958. Weed control programs for citrus and avocado orchards. Calif. Citrogr. 44: 60-61.

DAY, B. E., and C. D. MCCARTY

1957. Monuron for weed control in citrus. California Agr. Exp. Sta. Leaf. 95.

DAY, B. E., and L. S. JoRDAN

1961. Spray retention by bermudagrass. Weeds $9(3): 351-55$.

KRETCHMAN, D. W.

1961. Dalapon for controlling perennial grasses in Florida citrus groves. Down to Earth $16(4): 6-9$.

THIEGS, B. J.

1955. The stability of dalapon in soils. Down to Earth 11(2) : 2-4.

WESSELS, J. S. C., and R. VAN DER VEEN

1956. Action of some derivatives of phenylurethan and 3-phenyl-1, 1-dimethylurea on the Hill reaction. Biochim. et Biophys. Acta. 19: 548-49. 

The journal Hilgardia is published at irregular intervals, in volumes of about 600 pages. The number of issues per volume varies.

Subscriptions are not sold. The periodical is sent as published only to libraries, or to institutions in foreign countries having publications to offer in exchange.

You may obtain a single copy of any issue free, as long as the supply lasts; please request by volume and issue number from:

\author{
Agricultural Publications \\ Room 207 University Hall \\ 2200 University Avenue \\ Berkeley 4, California
}

The limit to nonresidents of California is 10 separate issues on a single order. $A$ list of the issues still available will be sent on request. 